\title{
Apical Extrusion of Debris by Manual and Mechanical Instrumentation
}

\author{
Lilia E. LEONARDI \\ Diana M. ATLAS \\ Guillermo RAIDEN
}

${ }^{1}$ Department of Endodontics, School of Dentistry, National University of Tucumán, San Miguel de Tucumán, Argentina

\begin{abstract}
The aim of the present study was to assess the presence of apically extruded debris and evaluate the influence of canal curvature on the amount of debris produced by manual and mechanical techniques. Forty single-rooted mature teeth with 15 to 30 degree of root canal curvature were selected. The presence of only one foramen was confirmed using a magnifying lens. A size $15 \mathrm{~K}$-file was placed up to the apical foramen to determine the patency. Working length was determined with the same instrument, 1 mm short of the foramen. According to the employed technique, the groups were labeled as follows: Group 1 - Manual instrumentation with Mor-flex files; Group 2 - Mechanical instrumentation with Cursor and Mor-flex files; Group 3 - Manual instrumentation with Flexi-cut files; Group 4 - Mechanical instrumentation with Cursor and Flexi-cut files. During instrumentation, the root canals were irrigated with $20 \mathrm{~mL}$. Debris extruded through the apical foramen was collected using the Myers and Montgomery technique. The values (in mg) were: Group 1: $0.422 \pm$ 0.683; Group 2: $0.688 \pm 0.795$; Group 3: $0.409 \pm 0.323$; Group 4: $0.810 \pm 0.708$. Data were analyzed statistically by ANOVA at 5\% significance level. There was no statistically significant difference among the groups ( $<<0.05)$. No statistically significant differences were found between slight and moderate curvatures in terms of the amount of extruded debris ( $>>0.05$ ).
\end{abstract}

Key Words: apical extrusion, manual instrumentation, mechanical instrumentation.

\section{INTRODUCTION}

During root canal instrumentation, necrotic debris, residual pulp tissue, microorganisms, dentin chips or irrigants can be forced towards the periapical area. This may lead to an inflammatory reaction and postoperative pain, so-called "flare-up" by some authors (1).

The assessment of the amount of debris extruded by different instrumentation techniques reveales that virtually all the techniques result in some degree of extrusion. Instrumentation techniques that involve filing movements would generate more apical debris $(2,3)$ because the file would act as a piston, pumping debris and irrigant solutions towards the periapical area (4). According to Reddy et al. (5), manual or mechanical instrumentation with rotary movements would significantly reduce the amount of debris because these techniques tend to pack dentin chips within the grooves of the file and expel them from the root canal. Furthermore, both the conical preparation of canal access and the crown-apex technique tend to produce less debris (2).

When instrumentation is coupled with irrigation, it tends to generate a significantly greater amount of debris than when irrigation is omitted (6). It is possible to remove larger amounts of debris by using larger amounts of irrigant solutions. Thus, although irrigation contributes to the removal of debris from the root canal and facilitates instrumentation, it would not avoid extrusion completely.

The aim of this study was to assess the presence of apically extruded debris and to evaluate the influence of canal curvature on the amount of debris produced by manual and mechanical instrumentation.

\section{MATERIAL AND METHODS}

Forty single-rooted, single-canal teeth with a mature apex, curvature between 15 and 30 degrees and a foramen accessible to instrumentation with a size 15 
K-file were selected. Lateral upper incisors, upper and lower canines and lower premolars were included in the study. Orthoradial radiographs were taken with a size 15 K-file inserted into the canal and then employed to determine curvature by Weine's technique.

Standard access was prepared, pulp tissue was removed and working length was visually determined at $1 \mathrm{~mm}$ of the apical foramen. The external surface was scraped with a curette to remove residual soft tissue, bone or tartar. Distilled water was used as the irrigant solution to avoid a potential increase in debris weight due to the formation of $\mathrm{NaOCl}$ crystals. After preparation with each instrument, the canals were irrigated with 2 $\mathrm{mL}$ of distilled water employing a \#25 G X 1 ( 0.50 x 25 $\mathrm{mm}$, Terumo) needle up to a total volume of $20 \mathrm{~mL}$ per tooth. The needle was placed inside the canal, as near as possible to the apical foramen, without exerting pressure on the canal walls. To evaluate the effect of curvature on debris extrusion, the teeth in each group were classified as slightly curved (angle of $15^{\circ}$ to $22^{\circ}$ ) or moderately (angle of $23^{\circ}$ to $30^{\circ}$ ) curved.

The specimens were assigne to 4 groups $(n=10)$ to include a similar number of slightly curved and moderately curved teeth. Group 1: Manual instrumentation with flexible, stainless steel K-type Mor-flex files (Moyco Union Broach, York, PA, USA); Group 2: Mechanical instrumentation with Cursor W\&H (W\&H Dentalwerk Burmoos GmbH, Austria) and Morflex files; Group 3: Manual instrumentation with flexible, stainless steel, type-K Flexi-cut files (Schwed Co Inc, Kew Gardens, NY, USA); Group 4: Mechanical instrumentation with Cursor and Flexi-cut files (Schwed Anteos).

\section{Debris Collection}

Debris collection was performed in keeping with the technique developed by Fairbourn et al. (2) and modified by Myers and Montgomery (7). Each tooth was forced through a rubber plug so it could be held easily during instrumentation. The extruded debris and irrigant solution were collected in a pre-weighed receptor tube, $5 \mathrm{~mm}$ in diameter and $10 \mathrm{~cm}$ in height, attached to the lower edge of the rubber plug. The apex was allowed to hang within the receptor tube. A wide-mouth bottle was used to hold the device during instrumentation. The system was sealed with rubber dam to avoid leakage of the irrigant into the receptor tube. The plug was pierced with a needle $(0.80 \times 25 \mathrm{~mm})$ to make the pressure inside and outside the bottle equal.

Once the instrumentation had been completed, the debris adhered to the root was scraped off with the inside surface of the tube. The receptor tubes were taken to an oven (DALVO, San Lorenzo, Santa Fe, Argentina) at $37^{\circ} \mathrm{C}$ containing $\mathrm{CaCl}_{2}$ anhidro crystals to absorb humidity. They were left there until the debris was dry. Before use, the receptor tubes were washed, labeled, dried in an oven containing $\mathrm{CaCl}_{2}$ and weighed six times.

\section{Debris Weighing}

The specimens were then weighed six times on a precision electronic balance $\left(10^{-4} \mathrm{~g}\right)$ (Acculab-R-LSeries LA 60, Totalcomp, Inc, Fair Lawn, NJ, USA) (max x 60 g). The weight of the debris was calculated as the difference between the pre and postinstrumentation weights. All instrumentation and weighing procedures were carried out by the same operator.

The control group comprised six tubes (3 empty and 3 containing 1,2 and $3 \mathrm{~mL}$ of irrigant) treated as described above.

The statistical analysis of the control group data was performed using the "paired t test for equal variances". The different instruments and techniques were compared by ANOVA and the "t test for different variances". A " $\mathrm{t}$ " test was employed to compare the debris for slight and moderate curvatures.

\section{RESULTS}

The debris extruded for each of the 4 groups is presented in Table 1. Extrusion of debris occurred in 36 of 40 canals. No statistically significant differences ( $>0.005$ ) were observed in the amount of apically

Table 1. Apical extrusion of debris in milligrams.

\begin{tabular}{lccc}
\hline Group (n=10) & Blockage & Means $( \pm$ SD) & Range \\
\hline (G1) Mor-flex/manual & 1 & $0.422 \pm 0.683$ & $0.2-1.9$ \\
(G2) Mor-flex/mechanical & & $0.688 \pm 0.795$ & $0.3-2.7$ \\
(G3) Flexi-cut/manual & 2 & $0.409 \pm 0.323$ & $0.1-0.8$ \\
(G4)Flexi-cut/mechanical & 1 & $0.810 \pm 0.708$ & $0.1-1.9$ \\
\hline
\end{tabular}


extruded debris between instruments and between instrumentation techniques. Regarding the weight means, the groups can be arranged in the following decreasing order: Group 4> Group 2> Group 1> Group 3.

Figure 1 illustrates the amount of debris extruded by the different techniques. No statistically significant differences $(\mathrm{p}>0.05)$ were found between specimens with slight and moderate curvatures in terms of the amount of extruded debris.

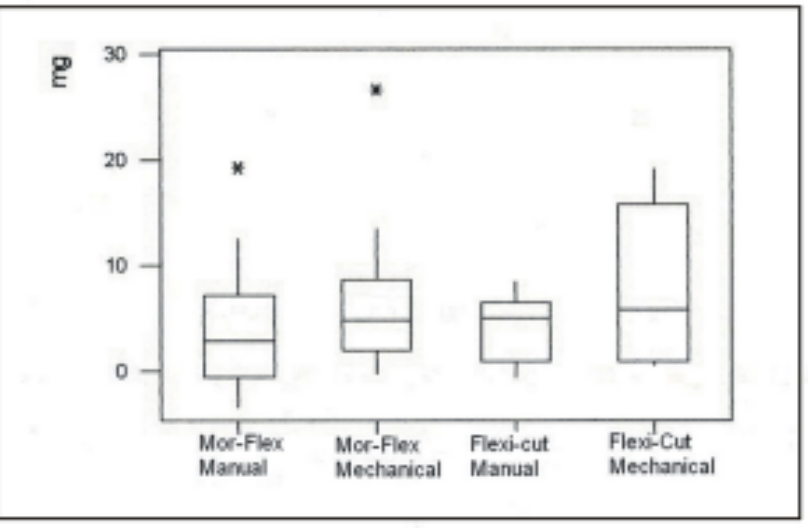

Figure 1. Box diagram showing the average amount ( \pm SD) of extruded debris for each group.

\section{DISCUSSION}

In this study, the debris was collected in collecting tubes and distilled water was used as the irrigant solution to avoid the formation of $\mathrm{NaOCl}$ crystals.

This study was based on the debris contained in the irrigant solutions collected or on the debris extruded through the foramen as a paste. In those cases in which there was no debris extrusion, we verified the presence of an apical dentinal plug by inserting a file. Myers and Montgomery (7) observed plugs in 16 of 19 teeth (84.2\%) instrumented to $1 \mathrm{~mm}$ from the foramen and in 4 of 39 teeth $(10.3 \%)$ instrumented to the foramen. In the present study, however, a dentinal plug was observed in 4 of 40 teeth (10\%) instrumented to $1 \mathrm{~mm}$ from the apical foramen.

This work revealed extrusion of the irrigant solution through the root canal in 15 of 40 cases (37.5\%). No differences were detected between manual
(7 of 20 cases) and mechanical (8 of 20 cases) techniques. The extrusion of the irrigant through the foramen may be attributed to the absence of a barrier of periapical tissue (8) and/or the action of gravity within the context of an in vitro study. The present study failed to reveal significant differences in the amount of apically extruded debris between the different instrumentation techniques and instruments.

The mean weights for the step-back technique presented herein are in agreement with those obtained by other authors with the hybrid technique $(9,10)$, the filing technique $(3,11)$ and the quarter-turn-pull technique $(3,6)$. However, they differ from those recorded by Mangalam et al. (10), who used a different filing movement. The present data also differ from the findings of Reddy et al. (5). This discrepancy may be due to the fact that these authors used sodium hypochlorite solution as the irrigant. As previously mentioned, sodium chloride crystals could result in an increase in weight.

The mean weight values recorded for mechanical instrumentation with Cursor are similar to the values obtained by Myers and Montgomery (7) with the Canal Master system. The weights for these techniques are larger than those obtained for nickel-titanium rotary systems $(5,9,12)$ and balanced force technique $(3,9,12)$. This difference could be attributed to the fact that the latter are crown-apex techniques and are coupled to conical preparation of the canal access that in turn reduces extrusion (2). Furthermore, the design of nickel-titanium instruments would remove the debris from the root canal (10).

The amount of debris forced apically by devices that are rotated and counter-rotated has not been sufficiently examined.

The present data, obtained in an in vitro study, should not be directly extrapolated to clinical practice. In keeping with other authors $(2,4,12-14)$, it may be consider that the persistence of residual pulp tissue or the presence of periodontal tissue or even granulation tissue in chronic periodontitis could act as natural barriers and limit apical extrusion in vivo.

\section{RESUMO}

O objetivo deste trabalho foi registrar a presença de material extruído apicalmente e estudar a influência da curvatura dos canais radiculares na quantidade de material, após a instrumentação manual e mecânica. Foram selecionados 40 dentes uniradiculares com ápice maduro, com curvatura do canal entre 15 e 30 graus e 
somente um forame apical. Verificou-se a patência do forame usando uma lima tipo-K no. 15 e se determinou a extensão de trabalho a $1 \mathrm{~mm}$ do forame. Considerando a técnica empregada, se formaram os seguintes grupos: Grupo 1 - instrumentação manual com limas Mor-flex; Grupo 2 - instrumentação mecânica com Cursor e limas Mor-flex; Grupo 3 - instrumentação manual com limas Flexi-cut e Grupo 4 - instrumentação mecânica com Cursor e limas Flexi-cut. Cada canal foi irrigado, enquanto era preparado, com $20 \mathrm{~mL}$ de água destilada. Para a coleta do material se aplicou a técnica proposta por Myers e Montgomery. Os valores, em miligramas obtidos em cada grupo foram: Grupo 1 - 0,422 \pm 0,683; Grupo 2 - 0,688 \pm 0,795; Grupo 3 - 0,409 \pm 0,323 e Grupo 4 - 0,810 $\pm 0,708$. A análise estatística (ANOVA) não detectou diferenças estatisticamente significantes $(\mathrm{p}>0,05)$ nas quantidades médias de material extruído em cada grupo. Comparando a influência da curvatura dos canais, não se encontrou diferenças estatisticamente significantes nas quantidades médias de material extruído segundo as curvaturas foram leves ou moderadas (test t para variâncias desiguais $p>0,05$ ).

\section{ACKNOWLEDGEMENTS}

Partially supported by CIUNT (Science and Technology of the National University of Tucumán).

\section{REFERENCES}

1. Seltzer S, Naidorf IJ. Flare-ups in Endodontics I. Etiological factors. J Endod 1985;11:72-78.

2. Fairbourn DR, McWalter GM, Montgomery S. The effect of four preparation techniques on the amount of apically extruded debris. J Endod 1987;13:102-108.

3. Al-Omari MAO, Dummer PMH. Canal blockage and debris extrusion with eight preparation techniques. J Endod 1995;21:154-158.
4. Brown DC, Moore BK, Brown CE, Newton CW. An in vitro study of apical extrusion of sodium hypochlorite during endodontic canal preparation. J Endod 1995;12:587-591.

5. Reddy SA, Lamar Hicks M. Apical extrusion of debris using two hand and two rotary instrumentation techniques. J Endod 1988;24:180-183.

6. Vande Visse JE, Brilliant JD. Effect of irrigation on the production of extruded material at the root apex during instrumentation. J Endod 1975;1:243-246.

7. Myers GL, Montgomery S. A comparison of weights of debris extruded apically by conventional filing and Canal Master techniques. J Endod 1991;17:275-279.

8. Salzgeber RM, Brilliant JD. An in vivo evaluation of the penetration of an irrigating solution in root canals. J Endod 1997;3:394-398.

9. Ferraz CCR, Gomez NV, Gomez BPFA, Zaia AA, Teixeira FB, Souza-Filho FJ. Apical extrusion of debris and irrigants using two hand and three engine-driven instrumentation techniques. Int Endod J 2001;34:354-358.

10. Mangalam S, Rao CVN, Lakshminarayanan L. Evaluation of apically extruded debris and irrigant using three instrumentation techniques. Endodontology 2002;14:19-23.

11. McKendry DJ. Comparison of balanced forces, endosonic, and step-back filling instrumentation techniques: quantification of extruded apical debris. J Endod 1990;16:24-27.

12. Hinrichs RE, Walker WA, Schindler WG. A comparison of amounts of apically extruded debris using handpiece-driven nickel-titanium instrument systems. J Endod 1998;24:102106.

13. Holland R, De Souza V, Nery MJ, de Mello W, Bernabé PFE, Otoboni Filho JA. Tissue reactions following apical plugging of the root canal with infected dentin chips. Oral Surg Oral Med Oral Pathol Endod 1980;49:366-369.

14. Beeson TJ, Hartwell GR, Thornton JD, Gunsolley JC. Comparison of debris extruded apically in straight canals: conventional filing versus Profile .04 Taper Series 29. J Endod 1998;24:18-22. 